\title{
Garap Gending Sekaten Keraton Yogyakarta
}

\author{
Subuh $^{1}$ \\ Jurusan Karawitan, Fakultas Seni Pertunjukan, Institut Seni Indonesia Yogyakarta
}

\begin{abstract}
ABSTRAK
Penelitian ini mengkaji faktor-faktor yang mempengaruhi garap gending sekaten keraton Yogyakarta. Metode deskriptif analitis digunakan untuk menganalisis unsur-unsur musikal gending melalui transkripsi notasi dan analisis garap. Gending sekaten merupakan salah satu jenis gending tradisi pakurmatan yang memiliki keunikan garap dan fungsi penting dalam upacara ritual. Gending ini menjadi bagian integral dalam tata upacara Keraton Yogyakarta. Dalam sebuah catatan dari masa Sultan Hamengku Buwono VIII, ditulis 63 titi laras gending, 16 di antaranya adalah gending khusus untuk sekaten yang ditulis lengkap dengan racikan yang digunakan dalam penyajian gending tersebut. Selebihnya adalah gending-gending mares (mars) atau gending gati. Berdasarkan penelitian dapat disimpulkan bahwa bahwa faktor yang mempengaruhi garap gending sekaten adalah keharmonisan antar unsur garap yang didominasi oleh pembonang sebagai pimpinan penggarap, karena bonang berfungsi sebagai pamurba lagu dan pamurba wirama, sedang pengrawit lainnya merupakan pendukung yang berkontribusi dalam suatu kerja kolektif untuk mewujudkan sajian yang ideal.
\end{abstract}

Kata kunci: gamelan, sekaten, Keraton Yogyakarta

\begin{abstract}
The Characteristics of Musical Lyrics on Indonesian Children Songs. The study tries to examine the discourse of Indonesian children songs. Indonesian children songs are songs that are composed for and sung by children in accordance with the child development stages. The purpose of this study is to describe the discourse of Indonesian children songs which describe their musical characteristics by giving more attention on words or lyrics of the songs. The characteristics of lyrics and musical characteristics that belong to each other are mainly a beautiful harmony in children songs. This study uses a descriptive method. The holistic method is employed to analyze children songs from some perspectives by doing the interview and distributing questionnaires to musicians, educators, teachers, parents, students, and common people in terms of composition background, the actual condition, and the resulted effect. The result shows that the Indonesian children songs have their own lyrics and musical characteristics as the followings: 1) the pattern of repeated musical rhythm, 2) the musically-repeated melody, 3) the repeated musical motives, and 4) the musically-repeated words. The function of Indonesian children songs is to learn a language of which the songs may also contain positive education values and characters for children by showing the meaningful words in the lyrics.
\end{abstract}

Keywords: children songs, lyrics, musical, Indonesian language

\section{Pendahuluan}

Gending sekaten termasuk dalam kelompok karawitan pakurmatan yang mempunyai fungsi dan garap khusus yang hanya dimiliki oleh kalangan terbatas seperti Keraton Yogyakarta, Keraton Surakarta,
Kasepuhan Cirebon (Sri Suwito, 2008: 3-6), dan Kadipaten Pakualaman Yogyakarta. Istilah pakurmatan menunjukkan spesifikasi fungsi gending yang biasa digunakan dalam sebuah upacara untuk menghormati salah satu mata acara dalam upacara tertentu (Sukistono, 2014: 181).

\footnotetext{
Alamat korespondensi: Jurusan Karawitan, Fakultas Seni Pertunjukan ISI Yogyakarta. Jalan Parangtritis Km 6,5 Yogyakarta. Tlp. (0274) 375380. E-mail: subuhisi@gmail.com
} 
Seperti gamelan pakurmatan yang lain, gamelan sekaten juga dipergunakan untuk upacaraupacara ritual khusus setiap keraton mempunyai hajat, sebagai tanda legitimasi kebesaran kerajaan. Gamelan sekaten diduga sudah ada sejak zaman Majapahit, sedang tradisi sekatenan yaitu penggunaan tradisi lokal yang digagas oleh para wali untuk syiar agama mulai ada sejak zaman Demak abad VIV (Supanggah, 2002 : 47-48). Pada zaman sekarang, gamelan sekaten ditabuh setahun sekali selama 1 minggu dari tanggal 5 sampai dengan 12 Mulud/Rabiul Awal dalam rangka memperingati lahirnya Nabi Muhamad S.A.W.

Keberadaan dan keterlibatan karawitan pakurmatan dalam upacara di Keraton Yogyakarta secara fungsional memiliki peran penting dan menjadi bagian integral dalam tradisi upacara keraton. Dari sejumlah empat ensamble gamelan pakurmatan di Keraton Yogyakarta (Monggang, Kodokngorek, Carabalen, dan Sekaten), ansamble Sekaten memiliki kekhususan dan keunikan baik secara organologi instrumen maupun komposisi gending, ragam dan teknik garap, serta fungsinya. Gamelan Sekaten berlaras pelog dengan "embat" yang "ageng" atau wilayah nada relatif lebih rendah dibandingkan dengan "embat" gamelan ageng pada umumnya. Dalam penyajian gending-gending Sekaten, karakter embat tersebut berkesan atau memiliki rasa musikal "agung-anteb" berkaitan dengan estetika.

Garap gending sekaten termasuk garap karawitan soran yaitu jenis tabuhan keras dengan ricikan/instrumen gamelan yang relatif berukuran besar dan tebal bila dibanding dengan gamelan ageng. Hal ini dimaksudkan agar dapat menghasilkan suara yang keras sesuai dengan fungsinya untuk memanggil masyarakat sebagai sarana dakwah (Supanggah, 2002: 49). Sebagaimana diketahui bahwa sajian karawitan garap soran tidak menggunakan ricikan lirihan seperti gender, rebab, gambang, siter, dan suling, serta tanpa kendang dan vokal.

Proses pewarisan unsur kebudayaan karawitan secara lisan memiliki potensi reinterpretasi, variasi, bahkan distorsi atau penyimpangan dari unsur kebudayaan semula. Hal ini disebabkan karena notasi/titi laras gending-gending sekaten hanya tertulis balungan-nya (melodi pokoknya) saja. Sementara detail garap dari masing-masing gending sekaten tidak terdokumentasikan secara tertulis.

Dalam sebuah catatan penting (Pemut Amemutra Pranatan Ungeling Kagungan Dalem Gangsa Sekati, 1 Kanjeng Kyai Gunturmadu, 2 Kanjeng Kyai Nagawilaga, 1952 : 1-98) pada masa Sultan Hamengku Buwono VIII , terdapat 63 gending untuk sekatenan. Dari enam puluh tiga gending yang ditulis, enam belas gending di antaranya adalah gending khusus untuk sekaten. Setiap gending ditulis lengkap dengan racikan (kalimat lagu yang dipergunakan untuk mengawali gending sekaten sebelum penyajian gending pokok). Selebihnya adalah gending-gending mares atau gending gati. Gending-gending khusus sekaten ini hanya diperdengarkan atau ditabuh pada saatsaat tertentu yaitu pada saat Upacara Sekaten atau upacara lain atas kehendak sultan (Mardawa, t.t.: 2-3). Keenam belas gending inilah yang akan ditabuh atau dibunyikan selama satu minggu meskipun tidak semua gending tersebut disajikan. Faktor penyebabnaya karena faktor kejenuhan atau dimungkinkan para abdi dalem niyaga tidak menguasai jenis gending sekaten tertentu. Faktor lainnya adalah kurangnya pengetahuan pengrawit dalam menggarap gending sekaten sebagai implikasi proses transmisi nonliteral atau verbal.

Untuk membahas ragam garap gending sekaten ini digunakan teori garap. Garap merupakan suatu rangkaian kegiatan seseorang atau sekelompok pengrawit, masing-masing memiliki tahapan dan cara kerja sendiri secara mandiri sesuai peran masing-masing, dalam satu kesatuan untuk menghasilkan sesuatu, sesuai dengan tujuan dan maksud yang ingin dicapai (Supanggah, 2009, 3). Garap di dalam karawitan merupakan kegiatan menafsir, mengolah, dan memikirkan suatu gending agar dapat disajikan dalam bentuk sajian yang estetis menurut kaidahkaidah konfensional dalam karawitan. Unsur-unsur garap di dalam karawitan meliputi: materi garap, penggarap, sarana garap, perabot dan piranti garap, penentu garap, dan pertimbangan garap (Supanggah, 2009: 4). Unsur-unsur garap tersebut juga sangat berpengaruh terhadap sajian gending sekaten. Keterkaitan antar unsur materi seperti 
bentuk balungan gending, kemampuan penggarap, format gamelan, irama dan laya, serta kedewasaan pengrawit juga ikut memberi bobot dan warna sajian gending sekaten.

\section{Ragam Garap Gending Sekaten Gaya Yogyakarta}

Faktor yang mempengaruhi garap gending sekaten antara lain materi garap dan penggarap. Materi garap berupa balungan gending yang terdiri atas lagu racikan dan lagu balungan gending, sedang penggarap adalah pengrawit yang menyajikan gending. Penggarap utama dalam penyajian gending sekaten adalah pembonang, karena bonang berfungsi sebagai pamurba lagu dan pamurba wirama, sedang pengrawit lainnya merupakan pendukung yang berkontribusi dalam suatu kerja kolektif untuk mewujudkan sajian yang ideal. Lagu racikan dan lagu balungan gending sudah terpola secara baku, seperti racikan gending sekaten patet lima, nem, dan barang.

Bentuk balungan gending sekaten terdiri atas balungan mlampah, balungan ngracik, dan balungan nibani. Balungan adalah kerangka pokok dari suatu gending, terdiri atas balungan lambal nibani irama I, II, III, balungan lugu irama III atau balungan ngracik irama II, dan balungan lugu irama I dan II (Suprapto, 2000: 54-55). Dalam artikel ini dibahas tiga balungan yaitu balungan lambal nibani, balungan mlakulmlampah untuk balungan lugu irama I dan II (Dwijoatmojo, 2010: 15), dan balungan ngracik untuk balungan lugu irama III atau ngracik irama II. Adapun contoh notasinya sebagai berikut:

$\begin{array}{llllllllll}\text { Balungan lambalnibani: } & \cdot & 2 & \cdot & 1 & \cdot & 3 & \cdot & 2 \\ \text { Balungan mlaku/mlampah: } & 5 & 3 & 2 & 1 & 3 & 5 & 3 & 2\end{array}$
Balungan ngracik: $\quad \begin{array}{llllllllllllllll}5 & 6 & 5 & 3 & 2 & 1 & 2 & 1 & 3 & 5 & 6 & 5 & 3 & 2 & 1 & 2\end{array}$

Pada balungan lambalnibani, setiap satu gatra terdapat empat tabuhan balungan yang membentuk unsur kalimat lagu, tetapi berisi titik/ pin pada ketukan kesatu dan ketiga. Pada bagian titik/pin inilah saron ditabuh dengan cara mancer, sedangkan pada ketukan kedua dan keempat ditabuh sesuai dengan not/titi laras lagu balungannya. Sementara ricikan demung ditabuh dengan cara imbal, demikian juga ricikan peking ditabuh dengan cara imbal kelipatan dua kalinya tabuhan demung.

Pada balungan mlaku/mlampah, setiap satu gatra terdapat empat tabuhan balungan yang membentuk unsur kalimat lagu. Kalimat lagu tersebut ada yang berisi penuh empat nada, tetapi ada juga dalam suatu gatra tertentu terdapat titik/ pin, tetapi tidak selalu pada hitungan kesatu dan ketiga. Sebagai contoh: 3656, 5415, 22.3, 356. dan seterusnya.

Balungan ngracik merupakan pengembangan/ perpanjangan balungan mlaku. Maknanya adalah dalam satu gatra yang berisi empat tabuhan balungan dikembangkan menjadi delapan tabuhan balungan atau satu gatra dikembangkan menjadi dua gatra. Hasilnya adalah seleh lagu pada tiap gatra kadang-kadang sama seperti gatra yang belum dikembangkan, tetapi kadang-kadang berubah, meskipun pada akhir kalimat lagu dalam satu kenongan pasti sama. Contoh notasinya sebagai berikut:

Balungan mlampah $\quad: \quad \begin{array}{lllllllll} & 3 & 6 & 5 & 6 & 5 & 6 & 5 & 3\end{array}$

Balungan ngracik : $\begin{array}{lllllllllllllll}6 & 7 & 5 & 6 & 5 & 5 & 5 & 6 & 7 & 5 & 6 & 3 & 5 & 2 & 3\end{array}$

Unsur materi garap dan penggarap sangat berpengaruh terhadap sajian gending sekaten. Materi garap di dalam gending sekaten dapat dikelompokkan menjadi dua yaitu gending-gending yang mempunyai persamaan garap dan gending-gending yang mempunyai spesifikasi garap. Gending-gending yang memiliki persamaan garap terdiri atas Gending Rendheng laras pelog patet lima, Salatun laras pelog patet nem, Atur-atur laras pelog patet nem, Ngajatun laras pelog patet barang, Bayem Tur laras pelog patet nem, Supiyatun laras pelog patet barang, Dhéndhang Subinah laras pelog patet nem, Sulatun laras pelog patet nem, dan Lara Tangis laras pelog patet nem. Adapun kelompok gending yang memiliki spesifikasi garap adalah Gending Rambu laras pelog patet lima, Rangkung laras pelog patet lima, Andhong-andhong laras pelog patet lima, Lung Gadhung Pel laras pelog patet lima, Burung Putih laras pelog patet nem dhawah Sobah, Dhendhang Subinah laras pelog patet nem, Gleyung laras pelog patet nem, Orang-aring laras pelog patet barang, dan Lenggang Rambon laras pelog patet barang.

Kelompok pertama dapat dikategorikan dalam kelompok bentuk ladrang, balungan mlampah. 
Dalam kelompok gending ini tidak terdapat balungan lamba/nibani dan balungan ngracik. Ciri bentuk ladrang kelompok ini dapat dilihat pada letak tabuhan instrumen strukturalnya yang terdiri atas bedug pengganti kempul, bonang bagian dhempok pengganti kenong, gong, kempyang dan bende berlaras 5 (lima) pada gamelan Kanjeng Kyai Guntur Madu atau bende berlaras 7 (barang) pada gamelan Kanjeng Kyai Naga Wilaga pengganti ketuk.

Kelompok kedua mempunyai ciri umum seperti kelompok pertama, tetapi mempunyai spesifikasi garap pada gending tertentu. Ciri-ciri itu antara lain Balungan lamba, mlampah, ngracik, garap tabuhan saron mlampah demung ngracik, dan demung imbal saron mancer. Bentuk balungan Gending Rambu adalah lamba, mlampah, dan ngracik. Bentuk balungan seperti ini menunjukkan bahwa Gending Rambu mempunyai struktur penyajian garap irama I, II, dan III. Ciri yang sama juga dapat dilihat pada Gending Rangkung, bahkan pada Gending Rangkung terdapat spesifikasi yang lebih khusus yaitu pada bagian ngelik disajikan dalam irama III tempo sangat lambat hingga seperti irama IV dengan bonangan dominan gembyang. Bentuk balungan Gending Andhong-andhong, Lung Gadhung Pel, dan Gending Lara Tangis pelog nem adalah nibani dengan garap demung imbal, saron mancer, dan bonangan dominan gembyang. Bentuk balungan Gending Burung Putih dhawah Sobah adalah ngracik sejak awal, sehingga jumlah Balungan terdiri dari 64 seperti gending berketuk loro kerep, pada bagian sesegan berbentuk balungan mlampah, tetapi struktur tabuhan kempyang, bende, bedug, kenong dan gong tetap mengacu pada struktur bentuk ladrang, sehinga tetap termasuk kategori bentuk ladrang. Pola penyajian Gending Burung Putih juga mempunyai spesifikasi tersendiri yaitu pada bagian pangkat dhawah ketuk pertama laya makin cepat, pada ketuk kedua semakin cepat seperti pada pola penyajian gending ketuk dua kerep, hingga berubah menjadi irama I sampai dengan gatra keempat belas melambat, dan gatra keenam belas sudah menjadi irama II.

Menurut analisis penulis terhadap Gending Burung Putih sebenarnya perubahan irama I ke II tidak harus dilakukan pada gatra keenam belas/ terakhir menjelang gong, tetapi dapat dilakukan pada Gending Sobah kenong ketiga, karena pada transisi ke Gending Sobah kenong I sampai dengan III ini masih berbentuk balungan mlampah, sehingga pada bagian ini dapat dipergunakan untuk transisi irama I ke II terus ke III. Setelah memasuki awal kenong IV baru menggunakan balungan ngracik (mulai irama III). Gending Gleyung dan Lenggang Rambon mempunyai spesifikasi garap pada bagian ngelik dengan tabuhan saron mlampah, demung ngracik. Gending Dhendhang Subinah mempunyai balungan ngracik dan balungan mlampah. Gending Orang-aring mempunyai balungan ngracik dan balungan lamba.

Dominasi pembonang sebagai penggarap sangat mempengaruhi warna garapan kelompoknya. Sebagai pamurba lagu dan pamurba irama ekspresi pembonang dilatarbelakangi oleh faktor pendidikan, pengalaman berolah karawitan, dan kedewasaan jiwanya dalam mengatur irama, laya, membuat cengkok-cengkok bonangan, dan harmonisasi sajian. Meskipun sajian gending pakurmatan termasuk seni tradisi, tetapi kebebasan berkreasi dan berimprovisasi secara terbatas tetap dipunyai oleh pembonang. Pembonang sekaten mempunyai sedikit kebebasan untuk mengembangkan variasi teknik bonangan, menentukan laya, dan pola penyajiannya.

Seni pada dasarnya merupakan hasil kerja kolektif yang dalam penciptaan/pengungkapannya melibatkan orang lain. Dalam melakukan proses kreatifnya seorang seniman akan berkomunikasi dan beriteraksi dengan orang lain di luar dirinya (Saepudin, 2013: 224). Maka dalam hal ini, kerja kolektif antara pembonang dengan pengrawit lainnya merupakan salah satu unsur yang dapat mempengaruhi keberhasilan sajian gending sekaten.

Dalam pelaksanaan sekaten, abdi Dalem niyaga Kawedanan Hageng Kridhamardawa Keraton Yogyakarta dibagi menjadi 4 reh (kelompok). Masing-masing kelompok menyajikan gending yang sama, tetapi warna, rasa, dan karakter sajiannya kadang-kadang berbeda. Sebagai contoh sajian gending sekaten yang dibawakan oleh Kelompok IV dengan pembonang Mas Bekel Puspo Katon selalu menyajikan gending sekaten dengan laya/tempo sangat lambat hingga sajian 
irama II seperti irama III, irama III seperti irama IV. Dalam sajian tersebut terlihat sangat kompak dan jarang terjadi kekacauan karena rasa dan komitmen penabuh kelompoknya dapat menyatu, meskipun di sisi lain kadang-kadang kalimat lagunya menjadi kabur.

Untuk menguaraikan ragam dan garap gending dalam tulisan ini akan dibagi menjadi dua kelompok yaitu kelompok gending yang dikategorikan dalam garap umum dan kelompok gending yang mempunyai spesifikasi garap.

\section{a. Kelompok Gending Garap Umum}

Pengertian garap umum dalam penulisan ini adalah persamaan garap antara gending satu dengan gending lainnya, baik mengenai struktur/ pola penyajian maupun bentuk balungan-nya. Struktur penyajian gending sekaten pada kelompok garap umum terdiri atas racikan, penyajian gending dalam irama II laya/tempo lambat, irama II laya agak cepat, sesegan (irama I) laya lambat, sesegan (irama I) laya agak cepat, sesegan (irama I) laya cepat, dan terakhir suwuk.

Adapun garap bonangnya adalah gembyang midak, gembyang lamba, gembyang dados, mipil lamba, dan mipil rangkep. Pengertian gembyang dalam garap gending sekaten berbeda dengan gembyang bonangan garap gending pada umumnya. Gembyang untuk bonang gending sekaten hanya ditabuh satu nada dengan aksen tabuhan gembyang, sedang gembyang bonang pada umumnya adalah ditabuh dua nada yang sama dengan antara dua nada. Ini dilakukan karena bonang sekaten tidak mengenal ambah-ambahan bawah dan atas. Demikian juga teknik tabuhan gembyang pada gamelan sekaten berbeda dengan teknik tabuhan gembyang pada gamelan ageng. Bonang pada gamelan sekaten meskipun susunan nadanya sama seperti bonang gamelan ageng yang terdiri atas deretan brunjung (atas) dan dhempok (bawah), tetapi tidak difungsikan sepenuhnya sebagai bonang pada gamelan ageng. Bonang deretan atas (brunjung) difungsikan sebagai bonang, sedang deretan bawah (dhempok) difungsikan sebagai kenong. Tabuhan gembyang dua nada sama hanya ditabuh sekali pada awal racikan yaitu pada nada 3/3 (dhadha).
Sebagai salah satu contoh penyajian gending kelompok garap umum, berikut ini akan dipaparkan Gending Réndhéng laras pelog patet lima. Gending Réndhéng adalah gending berbentuk ladrang dengan bentuk balungan mlampah. Penulisan nama tersebut sesuai dengan nama yang tertera dalam buku "Amemutra Pranatan Ungeling kagungan Dalem Gangsa Sekati”. Di dalam bahasa Jawa istilah rendeng (rèndèng) berarti tetuwuhan (tumbuh-tumbuhan), sedang rendheng (rêndhêng) berarti musim hujan. Kebenaran satu di antara dua nama tersebut tidak dapat ditelusuri karena tidak ada data atau narasumber yang dapat menerangkan hal tersebut.

Semua penyajian gending sekaten selalu diawali dengan racikan yang terdiri atas buka, dados, dan pangkat dhawah, dilanjutkan dengan penyajian gending yang diawali dari buka, dados, sesegan, dan suwuk.

Keterangan simbol, notasi:

B : bedug $\quad{ }^{-}$: bende sebelah kiri kempyang ${ }^{+}$: bende sebelah kanan . : kenong $\odot$ : gong

Notasi angka pada racikan bonang yang ditebalkan/ dibolt adalah tabuhan genjlengan balungan, notasi yang ditimpuk garis miring tabuhan yang dipathet.

\section{Racikan gending sekati kendang bedug, ketuk bende patet gangsal (lima)}

1. Buka:

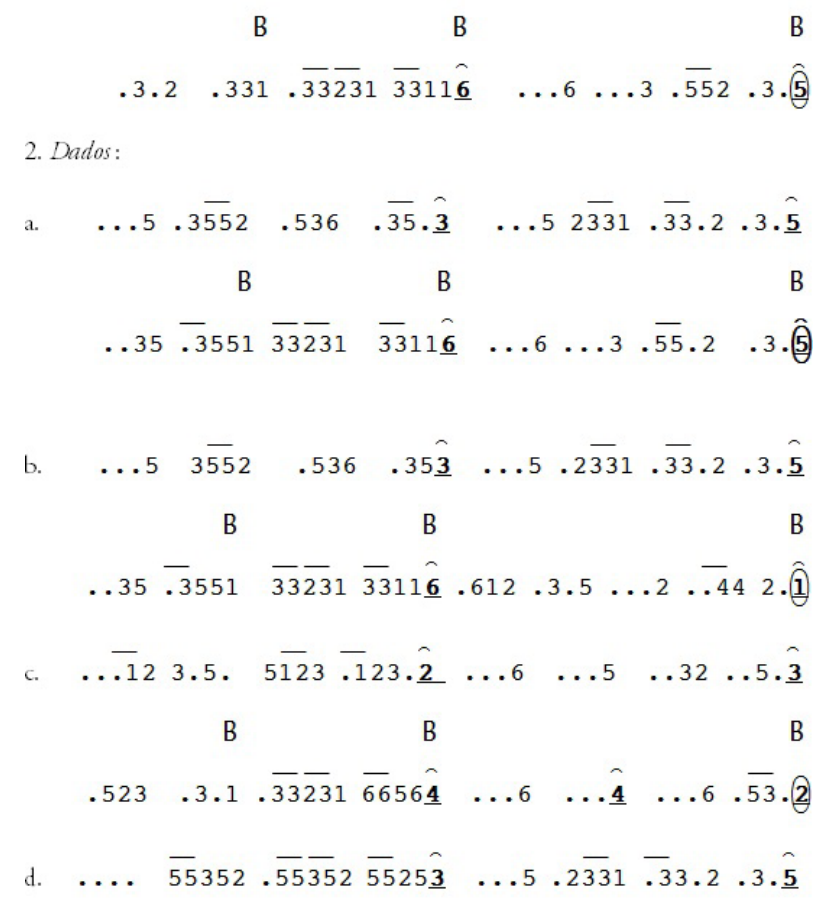




$$
\begin{aligned}
& \text { B B }
\end{aligned}
$$

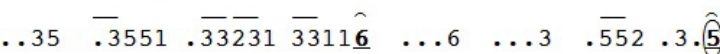

$$
\begin{aligned}
& \text { e. } \quad \begin{array}{llllllll}
\ldots 5 & 3 \overline{5} 52 & .536 & . \overline{35} \cdot \hat{\mathbf{3}} & \ldots 5 & . \overline{23} 31 & \overline{.3} 32 & .3 . \underline{\mathbf{5}}
\end{array} \\
& \text { B B }
\end{aligned}
$$

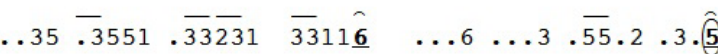

3. Pangkat dhawah

$$
\begin{aligned}
& \begin{array}{llllllll}
\ldots 5 & . \overline{35} 52 & .536 & .35 \underline{\hat{3}} & \ldots 5 & \overline{23} 31 & \overline{.3} 332 & .3 . \hat{5}
\end{array}
\end{aligned}
$$

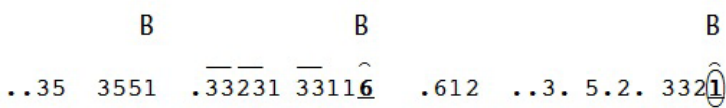

Racikan pelog lima terdiri atas tiga bagian: buka, dados, dan pangkat dhawah. Buka disajikan sekali, dados bagian a dapat disajikan berulangulang, tetapi biasanya hanya disajikan sekali terus ke bagian b , c, d, dan e. Bagian e adalah sama dengan bagian a, maka apabila racikan akan diulang, dari e dapat dilanjutkan ke b, c, d, dan e lagi tidak harus melewati bagian a. Untuk menuju ke gending yang akan disajikan dari e dilanjutkan ke bagian pangkat dhawah, dan diteruskan dengan buka gending. Pada kenong ketiga buka gending sebelum gong terakhir ricikan demung, saron, dan peking mulai ditabuh.

\section{Gendhing sekati Réndhéng kendang bedug ketuk bende patet lima}

1. Buka gending:

\section{B}

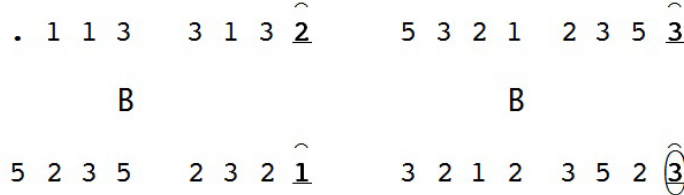

trus:

B

$\begin{array}{rlllllllll}3 & 2 & 3 & 133 & \hat{3} & .31 & 2 & 3 & 133 & 3\end{array}$

B

B

. $32235 \overline{311}$

Bn.:

$\underline{6} \underline{1} \underline{2} \underline{3} \quad \underline{2} \underline{1} \underline{2}$ (1)

$6 \overline{61} \overline{12} \overline{233} \overline{221} \overline{12} \overline{21} 1$

2. Dados:

A.

$\begin{array}{lllllllll}\text { Bal.: } & - & + & - & & - & + & - & 5\end{array}$

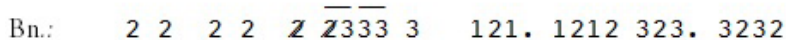

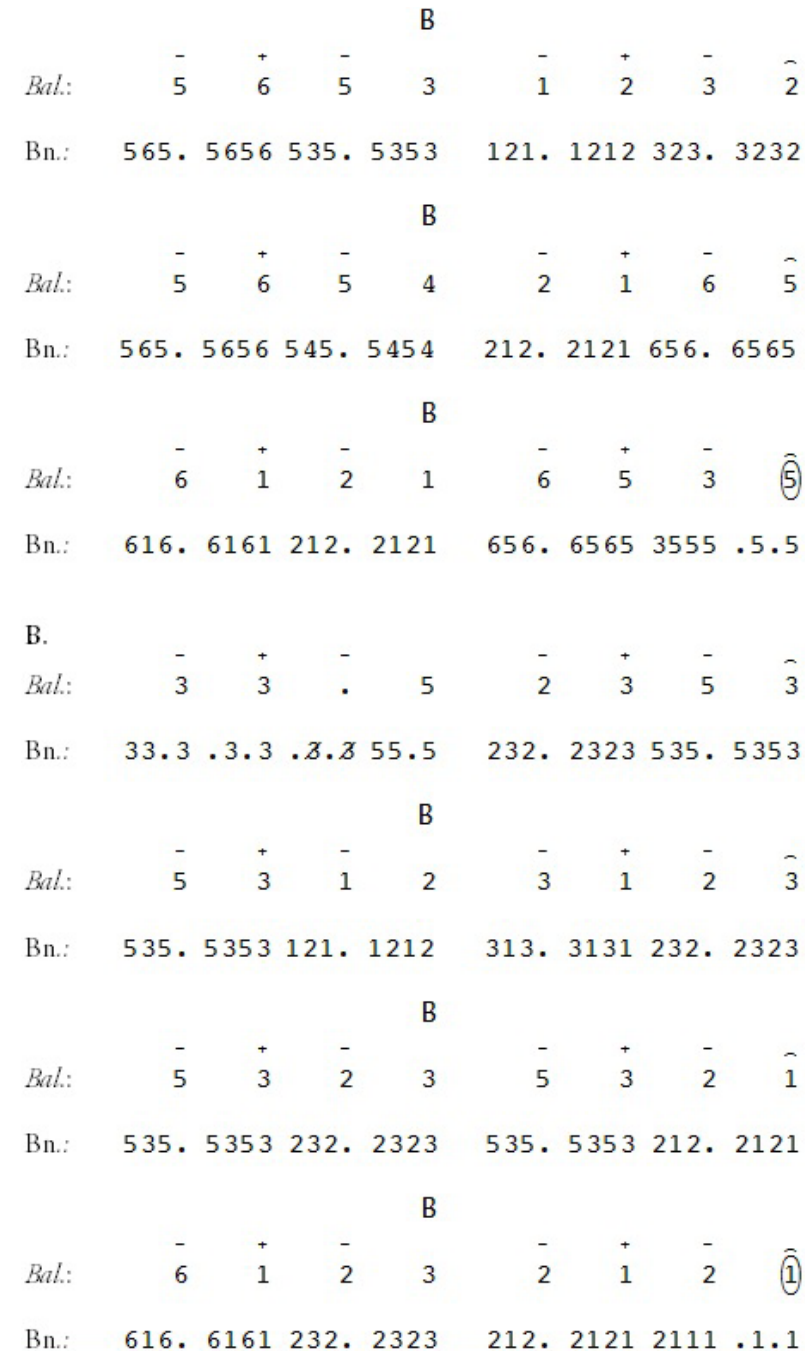

Garap bonang gembyang lebih banyak bonang gembyang midak, geter, dan nitir. Garap bonang mipil hampir selalu mipil lugu, jarang menggunakan ngrampat/mipil sekaran, karena bonang sebagai pamurba lagu dan pamurba wirama harus dapat menunjukkan lagu dan wirama dengan jelas. Notasi yang timpuk garis miring dapat diganti dengan titik.

Contoh:

Bal.:

$2 \quad 2 \quad \cdot \quad 3$

Bn. I:

$22.2 \quad .2 .2 \quad .2 .233 .3$

Bn.II:

$22.2 \quad .2 .2 \ldots 33.3$

\section{b. Kelompok Gending yang Mempunyai} Spesifikasi Garap

Di antara gending sekaten yang mempunyai spesifikasi garap adalah Gending Rambu laras pelog patet lima. Gending Rambu merupakan gending 
wajib yang harus disajikan pertama kali baik untuk gamelan sekaten Kangjeng Kyai Gunturmadu atau Kangjeng Kyai Nagawilaga pada malam hari (patet lima) atau pagi hari ketika Sri Sultan punya hajat ("Amemutra Pranatan Ungeling Kagungan Dalem gangsa Sekati, 1952”, 2013 : 5).

Seperti penyajian gending sekaten pada umumnya, struktur penyajian gending Rambu diawali dari racikan pelog lima, buka gending, penyajian gending sampai dengan suwuk.

\section{Racikan gending sekati kendang bedug, ketuk bende patet lima}

1. Buka:

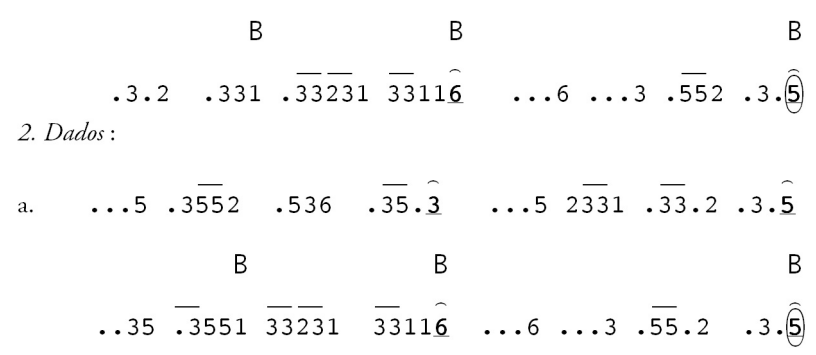

Bagian a dapat disajikan beberapa kali, tetapi dalam aplikasinya biasanya hanya disajikan sekali kemudian diteruskan ke bagian $b$.

$$
\begin{aligned}
& \text { b. } \quad \begin{array}{llllllll}
\ldots 5 & 3 \overline{55} 2 & .536 & .35 \hat{3} & \ldots 5 & .2 \overline{331} & . \overline{33} .2 & .3 . \hat{5}
\end{array}
\end{aligned}
$$

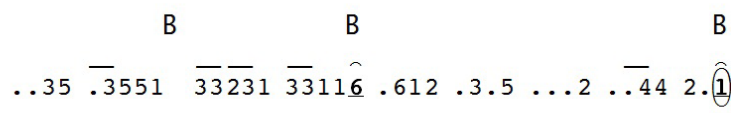

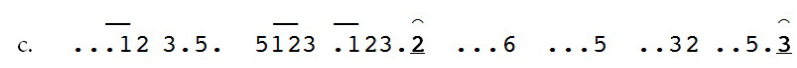

$$
\begin{aligned}
& \text { B B B } \\
& \begin{array}{lllllllll}
.523 & .3 .1 & . \overline{33} & \overline{23} 1 & \overline{66} 6 \hat{4} & \ldots 6 & \ldots .4 & \ldots 6 & . \overline{53} \cdot 2
\end{array} \\
& \text { d. } \quad \ldots \quad \overline{55352} . \overline{55352} \overline{5525 \hat{3}} \quad \ldots 5.2 \overline{331} \overline{.33} .2 .3 . \hat{5}
\end{aligned}
$$

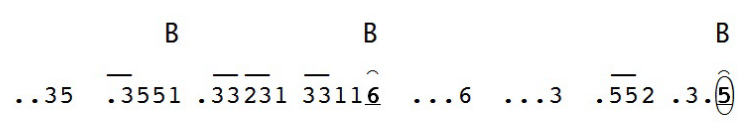

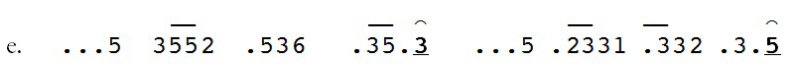

$$
\begin{aligned}
& \text { B B B } \\
& \begin{array}{llllllll}
\ldots 35 \overline{.3551} & . \overline{33} \overline{231} & \overline{3311 \hat{6}} & \ldots 6 & \ldots .3 & . \overline{55} .2 & .3 . \hat{5}
\end{array}
\end{aligned}
$$

3. Pangkat dhawah

$$
\begin{array}{llllllll}
\ldots 5 & . \overline{35} 52 & .536 & .35 \underline{3} & \ldots 5 & \overline{23} 31 & \overline{.0332} & .3 . \overline{5}
\end{array}
$$$$
\text { B }
$$$$
\text { B }
$$

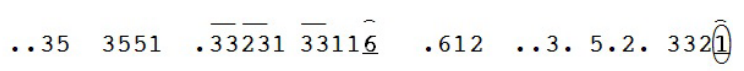

Buka Gending

$$
\begin{aligned}
& \text { B B } B
\end{aligned}
$$

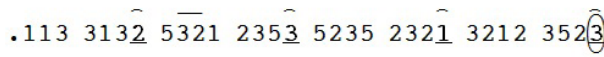

Trus:

$$
\begin{aligned}
& \text {. } 5 \begin{array}{lllllllllll}
5 & 36 & 3 & \overline{52} 2 & \overline{2} & .5 & 5 & \overline{44} & 54 & 2 & 1
\end{array} \\
& \text {. } 33 \text {. } 321 \underline{6} \quad \underline{6} \underline{6} \underline{6} \underline{5} \underline{3} \underline{2} \underline{3} \hat{5}
\end{aligned}
$$

Bn.:

Dados

A

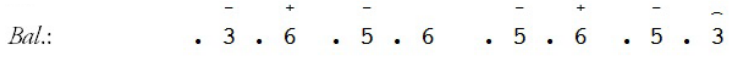

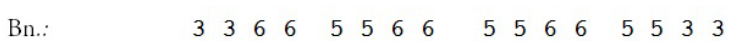

Garap bonang dalam satu kenongan pertama adalah gembyang midak.

Pengetikan selanjutnya dalam satu kenong akan dibagi menjadi dua baris khususnya untuk garap bonang pada balungan ngracik irama III.

Bal.:
Bn.:

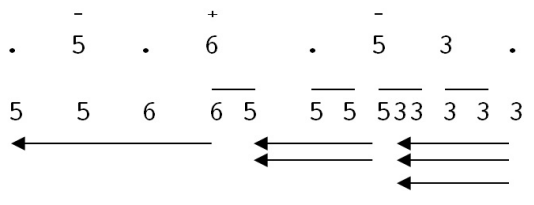

Garap bonang pada dua gatra berikutnya gembyang midak lamba, dados, dan rangkep, laya makin lambat karena pada dua gatra tersebut merupakan tempat di mana terjadi perubahan irama yaitu dari irama I ( kemudian III (

Garap bonang selanjutnya adalah mipil rangkep dan gembyang rangkep.

$$
\begin{aligned}
& \text { Bal: } \\
& \text { Bn.: } \\
& \text { Ball: } \\
& \text { Bn.: } \\
& \text { Bal: } \\
& \text { Bn.: }
\end{aligned}
$$$$
\begin{array}{llllllll}
6 & 5 & 3 & + & 1 & 2 & 3 & 2
\end{array}
$$

$656.656533 .3 .3 . . \quad 121.1212323 .3232$

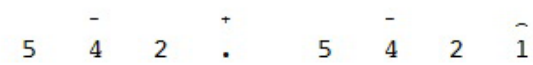

542.542422 .2 .2 .. 542.5424212 .2121 


\section{B}

Bal:

Bn.:

$565.5656 .6 .655 .5 \quad 636.636355 .5 .5 .5$

Bal: :

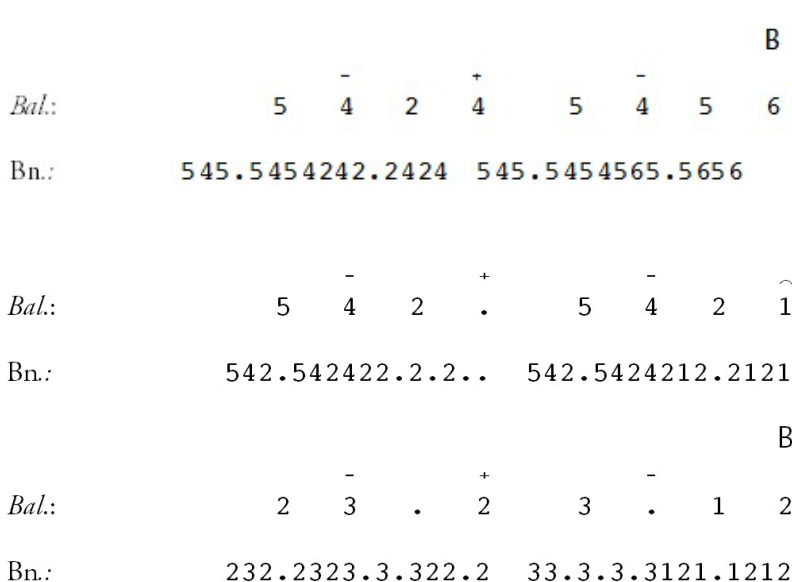

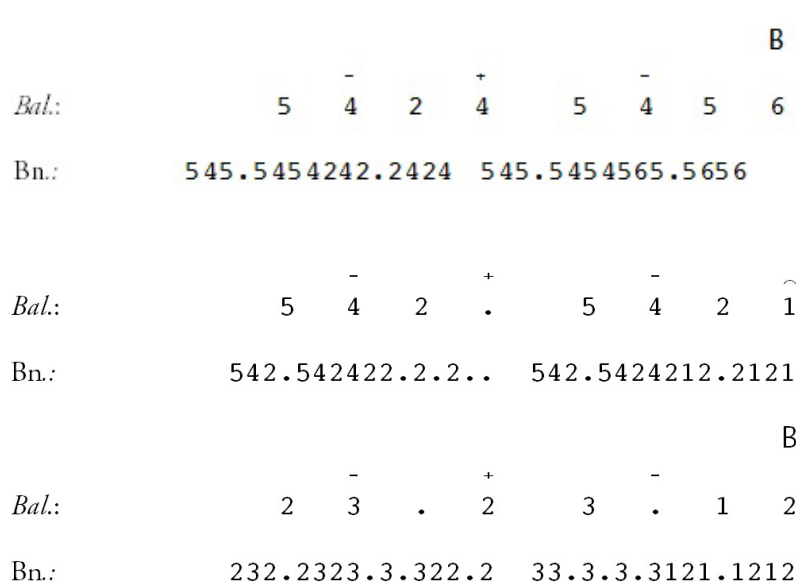

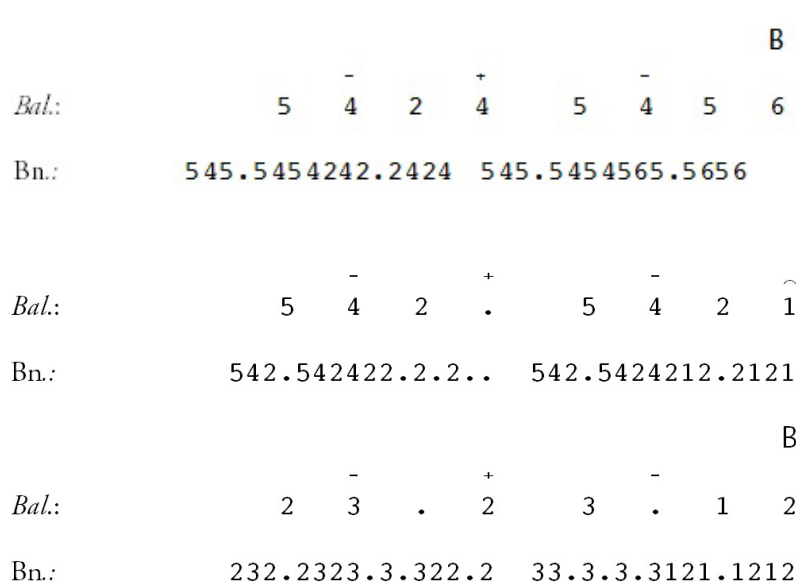

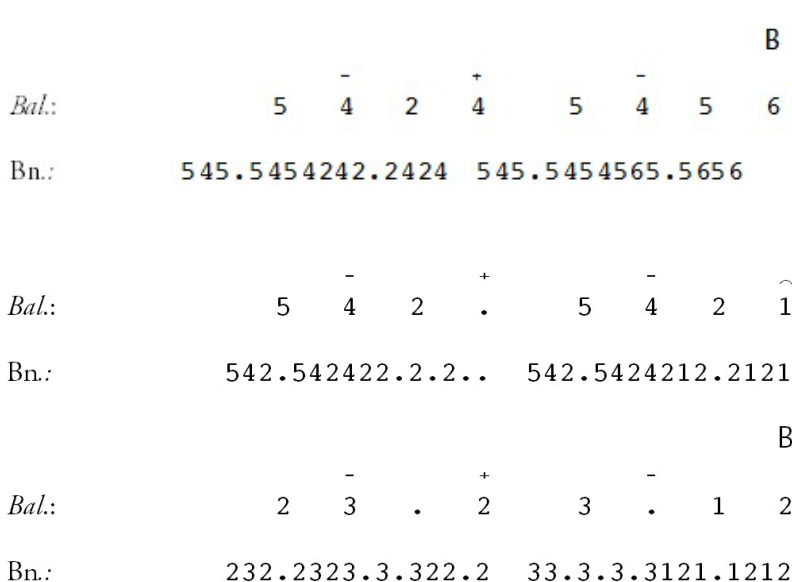

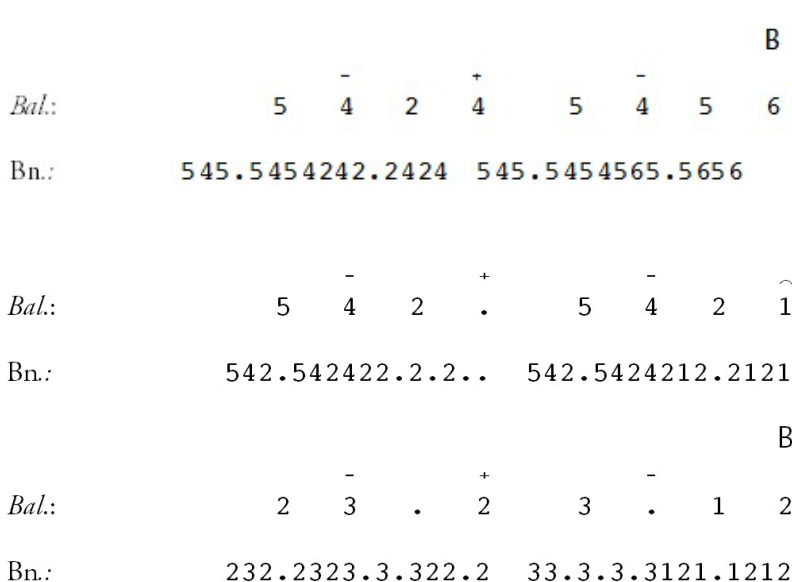

Bn.:

$\begin{array}{lllllllll} & & - & & + & & - & & \\ \text { Bal.: } & 3 & 5 & 6 & 5 & 3 & 2 & 1 & 6\end{array}$

Bn.:

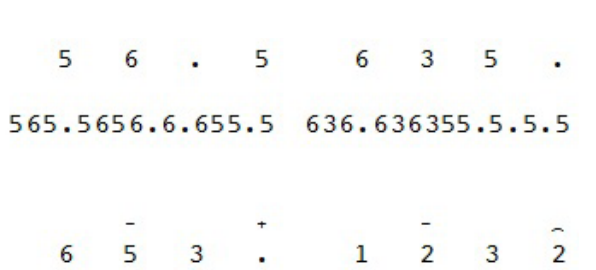

$656.656533 .3 .3 .3 \quad 121.1212323 .3232$

Garap Bonang pada kenong ketiga bagian

B gembyang. Tidak ditemukan jawaban mengapa demikian, tetapi menurut analisis penulis bahwa garap/lagu bonang pada kenong ketiga tersebut merupakan kesatuan dengan garap bonang berikutnya sampai dengan gong di antaranya terdapat garap bonang khusus menjelang gong pada balungan minjal seperti berikut.
\end{abstract}

Bal.:

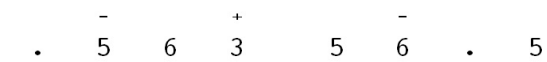

Bn.: $.16155 .5636 .6363 \quad 565.5656 .6 .655 .5$

Bal:

Bn.:

C

Bagian ini sebenarnya sama dengan A, tetapi pada bagian A satu kenongan pertama hingga tabuhan bedug pertama disajikan dalam irama I sebagai transisi ke irama III, sedang bagian C sepenuhnya disajikan dalam irama III.

Bal:

Bn.

\section{$676.6767565 .5656 \quad 353.3535232 .2323$}

B
$656.656533 .3 .3 .3 \quad 121.1212323 .3232$

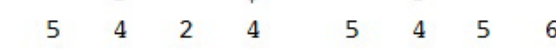

$545.5454242 .2424 \quad 545.5454565 .5656$

$542.542422 .2 .2 . \quad 542.5424212 .2121$

B

$\begin{array}{llllllll}2 & 5 & & + & & - & & \\ 2 & 3 & \cdot & 2 & 3 & \cdot & 1 & 2\end{array}$

$232.2323 .3 .322 .2 \quad 33.3 \cdot 3 \cdot 3121.1212$

$\begin{array}{llllllll}3 & 5 & 3 & 6 & 5 & 3 & 2 & 3\end{array}$

$353.3535363 .3636 \quad 535.53532333 .3 .3$

Pangkat neseg. Bagian ini sama dengan bagian A, tetapi dipergunakan untuk transisi ke irama I. Menjelang tabuhan kenong kedua laya/tempo mulai agak cepat $(\longrightarrow$ ) garap bonang mipil rangkep, pada tabuhan bedug kedua berubah menjadi irama II ( $\longrightarrow$ ) garap bonang mipil lamba, dan pada gatra terakhir menjelang tabuhan gong sudah menjadi irama I ( garap bonang gembyang midak.

Bal:

$\begin{array}{lllllll}5 & - & & + & & - & \\ 6 & 5 & 6 & 3 & 5\end{array}$

Bn.:

$565.5656 .6 .655 .5 \quad 636.636355 .5 .5 .5$

Bal:

Bn.:

$656.656533 .3 .3 .3 \quad 121.1212323 .3232$

Bal:

Bn.:

$545.5454242 .2424 \quad 545.5454565 .5656$ 
$\mathrm{Bn}$ :

542.542422 .2 .2$.

542.5424212 .2121

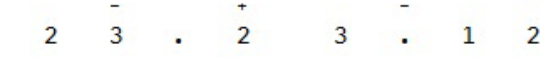

$232.2323 .3 .322 .2 \quad 33.3 .3 .31212$

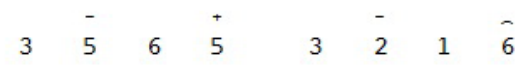

$\begin{array}{llllllllllllllll}3 & 5 & 3 & 5 & 6 & 5 & 6 & 5 & 3 & 2 & 3 & 2 & 1 & 6 & 1 & 6\end{array}$

B

$\begin{array}{lllllll} & 5 & 6 & 3 & 5 & 6 & .\end{array}$

$55.56363 \quad 565655.5$
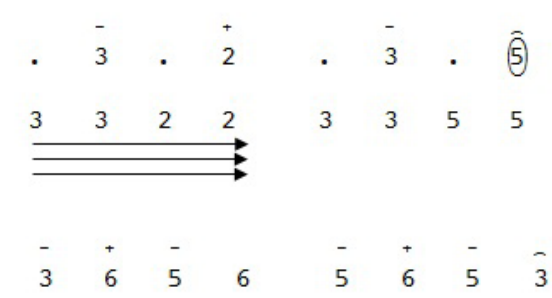

$\underline{3} \cdot \underline{3} \cdot \underline{3} \cdot \underline{3} \cdot \quad \underline{3} \cdot \underline{3} \cdot \underline{3} \cdot \underline{3} \cdot$

$6 \cdot 6 \cdot 6 \cdot 6 \cdot 6 \cdot 6 \cdot 6 \cdot 6 \cdot$

$\begin{array}{cccccccc} & & & \text { B } & & & & \\ - & + & - & & - & + & - & \\ 5 & 6 & 5 & 6 & 3 & 1 & 3 & 2\end{array}$

$\underline{3} \cdot \underline{3} \cdot \underline{3} \cdot \underline{3} \cdot \quad 31313232$

$6 \cdot 6 \cdot 6 \cdot 6$.

\section{B}

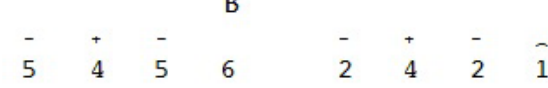

$\begin{array}{lllllllllllllll}5 & 4 & 5 & 6 & \overline{6} \cdot 6 & 6 & 6 & 2 & 4 & 2 & 4 & 2 & 1 & 2 & 1\end{array}$

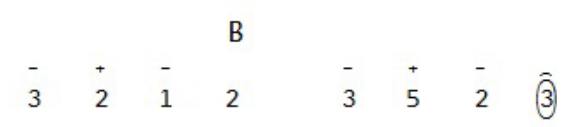

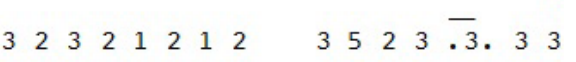

$\begin{array}{cccccccc}- & + & - & & - & + & - & - \\ 6 & 5 & 7 & 6 & 3 & 1 & 3 & 2\end{array}$

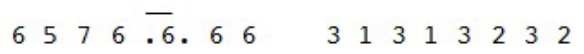

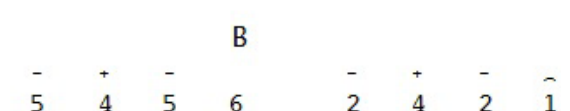

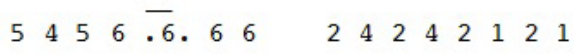

\section{B}

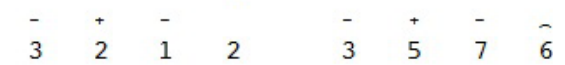

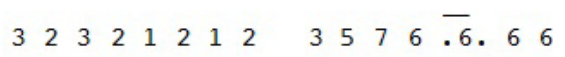

B

$\begin{array}{cccccccc}- & + & - & & - & + & - & \widehat{5} \\ 5 & 6 & 3 & 2 & 3 & 5 & 6 & \end{array}$

$\begin{array}{lllllllllllll}5 & 6 & 5 & 6 & 3 & 2 & 3 & 2 & 3 & 5 & 6 & 5 & \overline{.5}\end{array} .55$

Berdasarkan notasi tersebut, terdapat dua ragam garap pada bagian sesegan. Pertama berdasarkan kebiasaan dan keterangan dari pembonang terdahulu (K.M.T. Praba Asmoro, R.L. Lokasari, dan R.L. Wulan Karahinan) selama penulis ikut menabuh gamelan sekaten sejak tahun 1990-an hingga 2004-an, bagian sesegan selalu disajikan dalam irama I. Menurut analisis penulis hal ini sangat logis, karena kalau dicermati pada awal penyajiannya (pada bagian A) dari irama I dengan laya semakin lambat, setelah tabuhan bedug pertama langsung masuk ke irama III. Demikian juga pada transisi ke irama I (bagian D) saat menjelang disajikannya bagian sesegan dengan laya semakin cepat setelah tabuhan bedug ketiga langsung ke irama I dengan garap bonang gembyang midak. Hal lain yang memperkuat analisis ini adalah sebagaimana notasi yang tertulis pada Buku "Amemutra Pranatan Ungeling Kagungan Dalem Gangsa Sekati 1952" setelah bagian pangkat neseg kemudian langsung sesegan yang berarti laya/tempo cepat.

Kedua, berdasarkan keterangan K.R.T. Hendro Asmoro dan kebiasaan pembonang lainnya utamanya di kelompok I dan II, bagian sesegan ini sebelum disajikan dalam irama I terlebih dahulu disajikan dalam irama II, dengan alasan perubahan irama sebaiknya tidak melompat dari irama I langsung ke irama III, tetapi melewati irama II terlebih dahulu. Kedua ragam garap ini semuanya dapat diterapkan tergantung pembonang serta kesepakatan penabuh lainnya dalam satu kelompok. Suwukan

Bal.:

Bn.:

Bal.:

Bn.:

Bal.:

Bn.:

Bal.:

Bn.:

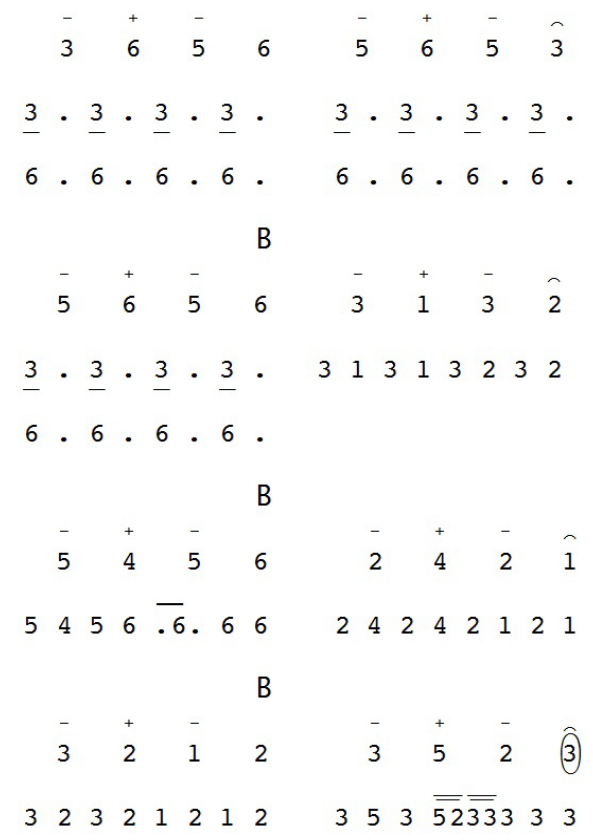




\section{Penutup}

Faktor yang mempengaruhi garap gending sekaten adalah materi garap dan penggarap. Materi garap berupa balungan gending yang terdiri atas lagu racikan dan lagu balungan gending, sedang penggarap adalah pengrawit yang menyajikan gending. Penggarap utama dalam sajian gending sekaten adalah pembonang, karena bonang berfungsi sebagai pamurba lagu dan pamurba wirama, sedang pengrawit lainnya merupakan pendukung yang berkontribusi dalam suatu kerja kolektif untuk mewujudkan hasil penyajian yang maksimal. Lagu racikan dan lagu balungan gending sudah terpola secara baku, seperti racikan gending sekaten/sekati patet lima, nem, dan barang. Bentuk balungan gending sekaten terdiri atas balungan mlampah, balungan ngracik, dan balungan nibani.

Materi garap di dalam gending sekaten dapat dikelompokkan menjadi dua yaitu kelompok gending yang mempunyai persamaan garap dan kelompok gending yang mempunyai spesifikasi garap. Dominasi pembonang sebagai penggarap sangat mempengaruhi warna garapan kelompoknya, karena ricikan bonang berfungsi sebagai pamurba lagu dan pamurba irama, sehingga pembonang mempunyai kebebasan (dalam konteks kebebasan terbatas) untuk mengekspresikan teknik tabuhan pribadinya, menentukan cepatlambatnya laya, dan jalannya pola penyajian. Ekspresi pembonang dilatarbelakangi oleh faktor pendidikan, pengalaman berolah karawitan, dan kedewasaan jiwanya dalam mengatur irama, laya, membuat cengkok-cengkok bonangan, dan harmonisasi sajian.

\section{Kepustakaan}

Anom, Gonjang, (Praba Asmoro, K.M.T.). (t.t.). Gendhing Sekaten Keraton Yogyakarta.

Asmoro, Hendro. (t.t.). "Gendhing-gending Sekaten Keraton Yogyakarta." Catatan Pribadi.

Atmojo Dwijo. (t.t.). "Gendhing-gending Sekaten Keraton Yogyakarta." Catatan Pribadi Gendhing-gending Sekaten Keraton Yogyakarta.

Atmojo, Dwijo. (2010) "Garap Tabuhan Karawitan Gaya Yogyakarta”. Makalah Dialog Interaktif dalam acara 'Pendhapa' disiarkan langsung melalui Programa IV RRI Yogyakarta.

Kriswanto, dkk. (2004). "Laporan Pelaksanaan Kegiatan Magang Karawitan Pakurmatan Yogyakarta; Nara Sumber R.L. Wulan Karahinan". Program Hibah Kompetisi A-1 Tahun Pertama Program Studi S-1 Seni Karawitan Jurusan Karawitan FSP ISI Yogyakarta.

Mardawa, Pustaka. (t.t.) Manuskrip. "Ing Ngandhap Punika Pratelan Kawontanipun Kagungan Dalem Gangsa Ing Karaton Ngayogyakarta Hadiningrat".

Puspo Katon. (t.t.). "Gendhing-gending Sekaten Keraton Yogyakarta." Catatan Pribadi.

Poerwadarminta, W.J.S. (1939) Baoesastra Djawa, J.B. Wolters Uitgevers Maatschappij NV. Batavia.

Saepudin, Asep. (2013). Garap Tepak Kendang Jaipongan dalam Karawitan Sunda. Yogyakarta: BP ISI. Url: http://digilib.isi. ac.id/id/eprint/1345.

Siswadi. (1987). "Sekaten di Karaton Ngayogyakarta Hadiningrat Satu Tinjauan Terhadap Penyajiannya”. Tugas Akhir Program Studi Sastra Karawitan Jurusan Karawitan Fakultas Kesenian Institut Seni Indonesia Yogyakarta. Subuh. (1986). "Gendhing-gendhing Mars atau Gati Kraton Yogyakarta: Satu Tinjauan Bantuk Penyajian, Fungsi dan Perkembangannya." Tugas Akhir Program Studi Sastra Karawitan Jurusan Karawitan Fakultas Kesenian Institut Seni Indonesia Yogyakarta.

Subuh. (1986). Gendhing-gending Sekaten Keraton Yogyakarta. Catatan Pribadi.

Sukistono, Dewanto. (2014). "Pengaruh Karawitan terhadap Totalitas Ekspresi Dalang dalam Pertunjukan Wayang Golek Menak Yogyakarta”. Resital Jurnal Seni Pertunjukan. Volume 15 No. 2 Desember. DOI: http:// dx.doi.org/10.24821/resital.v15i2

Sumanta Susilamadya. (2012). "Gendhinggendhing Sekaten Karaton Ngayogyakarta Hadiningrat". t.p. Yogyakarta.

Supanggah, Rahayu. (2002). Bothekan Karawitan

I. Jakarta: Masyarakat Seni Pertunjukan Indonesia (MSPI).

Supanggah, Rahayu. (2009). Bothekan Karawitan 
II: Garap. Program Pascasarjana bekerja sama dengan ISI Press Surakarta.

Suprabowo, Dedi Panggung. (2008). "Racikan

Pelog Lima Pada Gending Sekaten Rambu di

Keraton Yogyakarta: Satu Sudi Kasus". Skripsi

S-1 Program Studi Seni Karawitan Jurusan

Karawitan Fakultas Seni Pertunjukan Institut

Seni Indonesia Yogyakarta.

Suprapto. (1993). "Gamelan Pakurmatan Kraton

Yogyakarta.” Taman Budaya Propinsi Daerah Istimewa Yogyakarta.

Suprapto. (2000). "Karawitan Cara Ngayogyakarta
Hadiningrat, Cara Tabuh Bonang dan Tabuh Satu Saron dan Slenthem." Taman Budaya Propinsi Daerah Istimewa Yogyakarta.

Suwito, Yuwono Sri. (2008) "Upacara Sekaten dan Gamelan Sekaten”. Makalah disampaikan Lokakarya Gending Sekaten Gaya Yogyakarta yang diselenggarakan oleh Jurusan Karawitan FSP ISI Yogyakarta.

Tanpa Pengarang. (1952). "Pemut Amemutra Pranatan Ungeling Kagungan Dalem Gangsa Sekati, 1 Kanjeng Kyai Gunturmadu, 2 Kanjeng Kyai Nagawilaga". 


\section{INDEKS SUBJECT}

\section{A}

andung-andung 131, 135

apropriasi 19, 20, 21, 22, 23, 24, 25, 26, 27, 28

aspek 1, 2, 3, 4, 5, 8, 11, 15, 16, 17, 19, 21, 22, $29,36,46,47,62,66,78,82,95,96,101$, $118,121,123,126,127,129$

\section{B}

Barikin 140, 142, 143, 144, 145, 146, 147, 148, $149,150,151,152,153,154,156,157$

Batak Toba 131, 132, 133, 134, 135, 137, 138, 139

\section{C}

cecandetan 46,47

\section{D}

Dayak Benuaq 1, 2, 3, 4, 5, 6, 7, 8, 10, 12, 14, $15,16,17,18$

diatonik 87, 95

$\mathbf{E}$

estetika $5,17,18,19,20,21,22,24,26,28,29$, $45,60,70,71,73,75,76,82,86,134,136$, 138,179

\section{G}

gamat $19,20,21,22,23,24,25,26,28,29$

gamelan $5,7,13,14,18,46,50,51,53,58$, $60,61,62,63,66,141,143,152,165,169$, $178,179,180,181,182,184,186,188$

gamelan Jawa 5, 7, 13, 60, 61, 66

gêndér wayang $46,47,48,49,50,52,53,54$, $56,58,59$

gramatikal $118,121,122,123,126,127,129$

$\mathbf{K}$

karawitan Bali 46, 47, 48, 49, 50, 52, 54, 56, 58

kebudayaan Aceh 30, 31, 37, 44

kelentangan $1,2,3,4,5,6,7,8,9,10,11,12$, $13,14,15,16,17,18$

kêmpyang 51, 60, 61, 62, 63, 64, 65

kêmpyung 60, 61, 62, 63, 64, 66

Keraton Yogyakarta 178, 179, 180, 181, 182,
184, 186, 187, 188

komposisi musik sekolah 158, 159, 160, 168

kontekstual 19, 118, 126, 129

L

lagu anak-anak 119, 170, 171, 172, 174, 175, 176

lagu dolanan 46, 97, 118, 119, 120, 121, 122, $123,124,125,126,127,129$

lagu pendidikan 170

Lareh Koto Piliang 75, 76, 78, 80, 82, 84, 86

leksikal 118, 123, 129

Luhak Nan Tigo 22, 75, 82

M

Minangkabau 19, 20, 21, 22, 23, 24, 25, 26, 27, $28,29,45,75,76,77,78,79,80,81,82$, $83,85,86,170$

model pembelajaran 96, 158, 159, 160, 167, $168,169,176$

musik Borneo 140

musik daerah 19, 87, 93

musik lokal 3, 6, 87, 93, 95, 96

musik Minangkabau 19

musik perunggu $75,76,79,80,81,82,85,86$

musik Rapa'i 31, 32, 37, 38, 41

musik wayang 46

$\mathbf{O}$

ornamentasi $8,19,22,23,24,25,27,28,41$, $67,68,69,70,71,72,73,74,101$

\section{$\mathbf{P}$}

panting $140,141,142,143,144,145,146,147$, $148,149,150,151,152,153,154,155$, 156,157

pentatonik $8,87,95$

perkakas tangan $158,159,160,161,162,163$, $164,165,166,167,168$

piano concerto $98,99,100,101$

$S$

sekaten $178,179,180,181,182,183,184,186$, 187,188 
seni baca Al-Qur'an 67, 68, 69, 70, 71, 72, 73 seni Islami 30

seni suara $67,68,71,72,73,88,89,95$

Sepasang Mata Bola 98, 99, 103, 105, 109, 110, 112

siliran 60, 61, 63, 65, 66

sistem kekuasaan $75,76,78,79,80,81,82,84$, 85,86

\section{$\mathbf{T}$}

tema $40,41,42,43,44,65,66,83,91,92$, $94,95,96,98,99,101,102,103,105,107$, $109,110,114,115,116,135,165,170$, 171,172 transmisi musik $1,3,4,13,17$

$\mathbf{U}$

upacara kematian $131,132,137,138$

\section{V}

variasi $11,24,25,27,38,39,69,70,98,99$, $101,102,103,104,105,106,107,108$, $109,110,111,112,113,114,115,116$, $117,145,151,161,162,163,165,179$, 181

vokal $11,12,20,22,23,25,26,27,28,29,31$, $40,41,43,44,65,66,67,68,70,72,74$, $79,87,88,90,92,93,95,96,101,124$ 


\section{INDEKS PENGARANG}

Anderiani, Lupi 140

Dewi, Maria Octavia Rosiana 98

Ediwar 30

Elis N. M., Endang Retnaningdyah 118

Ganap, Victor 19, 67, 131

Haryono, Slamet 170

Haryono, Timbul 1, 19, 131

Irawati, Eli 1

Martarosa 19

Nugraha Ch. R, Wisma 1
Purnama, Arif 158

Putro, Ign. Nuryanto 190

Sastra, Andar Indra 75

Simatupang, GR Lono Lastono 19, 67, 131

Subuh 178

Sukmayadi, Yudi 158

Suneko, Anon 60

Suryati 67

Tindaon, Rosmegawaty 131

Utomo, Udi 87

Wadiyo 87,170

Yasa, I Ketut 45

\section{Ucapan Terima Kasih}

Ucapan terima kasih disampaikan kepada para Mitra Bebestari:

Prof. Dr. I Nyoman Sedana (Institut Seni Indonesia Denpasar)

Prof. Dr. Djohan (Institut Seni Indonesia Yogyakarta)

Prof. Dr. Endang Caturwati (Institut Seni dan Budaya Bandung)

Prof. Dr. Ted Tsung Tsai (Graduate School of Ethnomusicology, Tainan National University of the Arts, Taiwan)

Dr. Made Mantle Hood (University Putra Malaysia)

Dr. Ratna Noviani (Kajian Media dan Budaya, Universitas Gadjah Mada Yogyakarta)

Dr. Wisma Nugraha Chr (Universitas Gadjah Mada Yogyakarta)

yang telah membantu menyeleksi artikel dan memberi saran perbaikan kepada para penulis Jurnal Resital Volume 17 No. 1 April 2016, Volume 17 No. 2 Agustus 2016, dan Volume 17 No. 3 Desember 2016. 